\title{
Influence of low levels of water salinity on toxicity of nitrite to anuran larvae
}

\author{
C. Shinn ${ }^{\mathrm{a}, \Uparrow}$, A. Marco ${ }^{\mathrm{a}}$, L. Serrano ${ }^{\mathrm{b}}$ \\ ${ }^{a}$ Estación Biológica de Doñana, CSIC, C/Americo Vespucio, s/n, 41092 Isla de la Cartuja, Sevilla, Spain \\ ${ }^{\text {b }}$ Departamento de Biología Vegetal y Ecología, Universidad de Sevilla, PO Box 1095, 41080 Sevilla, Spain
}

Keywords:

Nitrite

Salinity

Amphibian larvae

Sub-lethal effects

\section{a b s t r a c t}

Reactive nitrogen compounds such as nitrite $\left(\mathrm{NO}_{2}^{-}\right)$are highly toxic to aquatic animals and are partly responsible for the global decline of amphibians. On some fish and Caudata amphibian species low levels of sodium chloride significantly reduce the toxicity of nitrite. However, the nitrite-salinity interaction has not been properly studied in anuran amphibians. To verify if chloride $\left(\mathrm{Cl}^{-}\right)$attenuates $\mathrm{NQ}^{-}$toxicity, eggs and larvae of three anuran species were subjected to a series of $\mathrm{NQ}^{-}$solutions combined with three salt concentrations ( $0,0.4$ and 2 or $0,0.052$ and $\left.0.2 \mathrm{~g} \mathrm{~L}^{-1} \mathrm{NaCl}\right)$. One of the species tested originated from two different populations inhabiting highly contrasted nutrient richness environments: lowland Doñana Natural Park and Sierra de Gredos Mountain. In general, the presence of $\mathrm{Cl}^{-}$increased survival and growth of lowland Pelophylax perezi and activity of mountain P. perezi larvae exposed to $\mathrm{NQ}_{2}^{-}$, thus attenuating the toxicity of $\mathrm{NO}_{2}^{-}$to developing amphibians. Mountain amphibian populations appeared to be much more sensitive to the concentrations of $\mathrm{NO}_{2}^{-}$and $\mathrm{Cl}^{-}$used in this experiment than coastal conspecifics, suggesting possible adaptation of populations to local conditions. Nitrogen pollution in coastal wetlands poses a serious threat to aquatic organisms, causing direct toxicity or indirect effects via ecosystem eutrophication. The presence of low to medium levels of salinity that would be common in coastal wetlands may attenuate the direct effects of increasing concentrations of nitrogenous compounds in water bodies. Furthermore, treating cultures of endangered anurans with small amounts of $\mathrm{NaCl}$ may provide an additional protective measure.

\section{Introduction}

Nitrogen-based agricultural fertilizers are one of many anthropogenic contaminants having serious effects on natural ecosystems, especially surface freshwaters. Of the total nitrogen applied to agricultural land, only a small portion is required by plants to grow; the excess accumulates in the soil, leaches into adjacent water bodies, or enters groundwaters and the atmosphere (Vitousek et al., 1997). Eutrophic conditions in surface waters can

$\Uparrow$ Corresponding author. Present address: IMAR-Instituto do Mar, c/o Dep. Ciências da Vida, Univ. Coimbra, 3004-517 Coimbra, Portugal. Tel.: +351 239836386; fax: +351 239823603.

E-mail addresses: candida.shinn@gmail.com (C. Shinn), amarco@ebd.csic.es (A. Marco), serrano@us.es (L. Serrano). arise due to a small excess of nitrogen, resulting in a decrease in dissolved oxygen. Eutrophication-induced anoxia or hypoxia has been reported to cause biodiversity losses, outbreaks of nuisance species and alteration of food chain structures (Vitousek et al., 1997; Smith et al., 1999). The degradation of water resources can also cause the loss of ecosystem services, leading to economic effects (Carpenter et al., 1997).

Several studies have reported the toxic effects of nitrogenous compounds on various aquatic organisms including fish, invertebrates and amphibians (Marco et al., 1999; Randall and Tsui, 2002; Alonso and Camargo, 2004). Of all intervening compounds of the nitrogen cycle, nitrite $\left(\mathrm{NO}_{2}^{-}\right)$is one of the most toxic when present in an already unbalanced environment (Wetzel, 2001; Marco and Ortiz-Santaliestra, 2009). Once absorbed into an organism, $\mathrm{NO}_{2}^{-}$reacts with haemoglobin and oxidizes ferrous iron to 

ferric iron, thus producing methaemoglobin, which in turn cannot bind or transport oxygen, thereby causing tissue hypoxia (US EPA, 1986).

Ponds and lakes adjacent to agricultural fields are particularly vulnerable environments as toxic compounds such as fertilizers and pesticides can reach the aquatic system directly via runoff. Toxic and even lethal concentrations of $\mathrm{NO}_{2}^{-}$can occur in this type of closed aquatic systems (Bogardi et al., 1991). However, studies on the impact of $\mathrm{NO}_{2}^{-}$exposure to fish species have resulted in contradictory results. Fish tolerance to nitrite exposure may increase in environments with greater salinity (Crawford and Allen, 1977; Lewis and Morris, 1986; Sampaio et al., 2002). The key factor to such results is the attenuating effect of monovalent ions, such as chloride $\left(\mathrm{Cl}^{-}\right)$, on the toxicity of $\mathrm{NO}_{2}^{-}$to organisms (Perrone and Meade, 1977). Membrane flux studies have revealed that $\mathrm{NO}_{2}^{-}$is a competitive inhibitor of $\mathrm{Cl}^{-}$uptake, and vice-versa (Williams and Eddy, 1986). For instance, fish species with greater $\mathrm{Cl}^{-}$uptake rates are more sensitive to $\mathrm{NO}_{2}^{-}$than species with lower $\mathrm{Cl}^{-}$uptake rates (Williams and Eddy, 1986). Therefore, ambient $\mathrm{Cl}^{-}$can ameliorate $\mathrm{NO}_{2}^{-}$toxicity through competitive inhibition (Perrone and Meade, 1977; Bath and Eddy, 1980; Alonso and Camargo, 2008). In fact, adding calculated quantities of chlorine to aquaculture water systems is a way of protecting freshwater fish from $\mathrm{NO}_{2}^{-}$contamination (Francis-Floyd, 1995). In the whole, as the concentration of $\mathrm{Cl}^{-}$in the water increases, the capacity of the $\mathrm{NO}_{2}^{-}$ions to enter the blood stream decreases (Lewis and Morris, 1986; Alonso and Camargo, 2008).

Nitrogen pollution has been appointed as one of the major causes for the ongoing global amphibian population decline (Blaustein et al., 2003). Several studies have demonstrated the toxic effects of $\mathrm{NO}_{2}^{-}$on amphibian larval stages (Huey and Beitinger, 1980a, 1980b; Marco and Blaustein, 1999; Marco et al., 1999; Griffis-Kyle, 2005). However, there is also a strong variability in sensitivity to $\mathrm{NO}_{2}^{-}$among species and even among different studies conducted on the same species (Marco and Ortiz-Santaliestra, 2009). Genetic, maternal or ontogenetic effects may explain part of this variability (Gomez-Mestre and Tejedo, 2003; OrtizSantaliestra et al., 2006; Shinn et al., 2008). As occurs in fishes, environmental factors such as the presence of small amounts of $\mathrm{Cl}^{-}$in some freshwater bodies may also explain the low toxicity of $\mathrm{NO}_{2}^{-}$to amphibians in some studies. Huey and Beitinger (1980a) found that relatively low test concentrations of $\mathrm{Cl}^{-}$protected Ambystomatexanum larvae from the toxic effects of $\mathrm{NO}_{2}^{-}$. This species suffered a $0 \%$ mortality rate at $3 \mathrm{mg} \mathrm{L}^{-1} \mathrm{~N}-\mathrm{NO}_{2}^{-}$in the presence of high test concentrations of $\mathrm{Cl}^{-}\left(300 \mathrm{mg} \mathrm{L}^{-1}\right)$. A. texanum exposed to $\mathrm{NaNO}_{2}$ at low concentrations of $\mathrm{Cl}^{-}$had a $96 \mathrm{~h}$ LC50 (Lethal Concentration to half of tested individuals) of $0.33 \mathrm{mg} \mathrm{L}{ }^{-1} \mathrm{~N}-\mathrm{NO}_{2}^{-}$, and a $100 \%$ mortality rate when larvae were exposed to $0.76 \mathrm{mg} \mathrm{L}^{-1} \mathrm{~N}-\mathrm{NO}_{2}^{-}$(Huey and Beitinger, 1980b). Conversely, a recent study of Ortiz-Santaliestra et al. (2010a) revealed synergistic lethal effect of salinity and ammonium nitrate in a Pelophylax perezi population that was not naturally exposed to high salinity levels. This was not observed in P. perezi individuals collected from ponds with higher salinity, suggesting population-level adaptation to salinity.

The present study has experimentally assessed the effects of low levels of salinity over $\mathrm{NO}_{2}^{-}$toxicity in larval stages of three anuran species, testing the interaction between $\mathrm{Cl}^{-}$and $\mathrm{NO}_{2}^{-}$. Amphibians do not tolerate high levels of salinity (over $5 \mathrm{~g} \mathrm{~L}^{-1}$ ) but can develop in waters with low levels of salt. When comparing different amphibian habitats, salt concentrations usually vary within 0 and $5 \mathrm{mg} \mathrm{L}^{-1}$ (Gomez-Mestre and Tejedo, 2003). Low concentrations of sodium chloride $(\mathrm{NaCl})$, often found in amphibian habitats, were used to verify whether low levels of salt can reduce the toxicity of $\mathrm{NO}_{2}^{-}$to anuran larvae.

\section{Materials and methods}

\subsection{Study areas}

In all studies, amphibians were handled in accordance with national and international guidelines for the protection of animal welfare (Directive 86/609/EEC; European Union, 1986; in force at the time the studies were conducted). Amphibian eggs and larvae were collected from ponds located in the lowland, coastal marshland area of the Doñana Natural Park (DNP) and in the inland Sierra de Gredos mountain (GM). Authorization for the collection from the wild and use of the organisms in experiments was obtained from the Consejaría de Medio Ambiente de Andalucía, the Consejaría de Medio Ambiente de Castilla y León, and from the head offices of the Parque Nacional de Doñana and of the Parque Regional de la Sierra de Gredos.

The Doñana region is located on the Atlantic coast of southwestern Spain. This region includes an extraordinary variety of aquatic systems and some of them exhibit the highest degree of environmental protection in Spain. Outside the protected areas, watersheds are severely altered by human activities. The lower valley of the Guadalquivir River is devoted to agriculture (traditional cultivars of olive trees, irrigated crops, and rice fields) as well as farming of cattle and horses. The water chemical composition of the Doñana wetlands is mainly influenced by rainfall, evaporative concentration, groundwater discharge, biogeochemical interactions at the sediment-water interface, and the water quality of their watersheds (Serrano et al., 2006). The Doñana marshland is a silty-clay floodplain which is seasonally fed by rainfall and river outflow, and to a much lesser extent, tidal water. High dissolved nutrient concentrations (maximum $\mathrm{NO}_{2}^{-}$concentrations can reach $0.47 \mathrm{mg} \mathrm{L}^{-1}$ maximum) is the main cause of poor water quality in the various river basins, while high inorganic suspended matter is the main cause of pollution in floodplains fed by the tidal water from the estuary of the Guadalquivir River (Serrano et al., 2006). Both the solubilization of salts from the dry sediment and the concentrative effect of evaporation ensure a relatively high mineralization level, though salinity drops markedly during heavy floods and hence conductivity has been reported to vary from 2 to $>30 \mathrm{mS} \mathrm{cm}^{-1}$ across the Doñana marshland in the same year (Serrano et al., 2006). Frogs in the DNP breed in late winter or early spring in shallow warm, eutrophic water.

The Sierra de Gredos Mountain is located within the Iberian Peninsula Central Range. The main anthropogenic stressors on GM are cattle and intense tourism, both causing eutrophication of lake and pond waters due to terrain erosion and deposition of biological waste. Wastewater discharge into a lake due to faulty wastewater treatment installations of a mountain refuge has been reported in the area. The GM is covered by snow for 5-7 months of the year, with water levels in lakes responding rapidly to temperature increase in the spring. At the altitude of the study (around 1900 m.a.s.l.) the habitat is of humid meadows with ponds and rapid streams that are fed principally by heavy rain events. The mean water conductivity is very low in GM, varying between 4 and

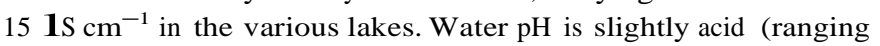
between 6.2 and 6.8 in lakes and going as low as 5.6 in streams), contributing to a very low buffering capacity in surface waters. Nitrate concentration is low ( $<60 \mathbf{l g ~ L}{ }^{-1} \mathrm{~N}-\mathrm{NO}_{3}$ ), ammonium concentration is usually under $90 \mathbf{I g ~ L}^{-1} \mathrm{~N}-\mathrm{NH}_{4}$, and total phosphorus concentrations do not exceed $25 \mathbf{I g ~ L}^{-1}$. Pond water temperatures during the amphibian breeding season - mid-April to mid-June - vary from $6{ }^{\circ} \mathrm{C}$ to $20^{\circ} \mathrm{C}$ and ponds occasionally dry-up in the summer (Lizana and Pedraza, 1998). Thus, GM frog populations breed in colder and more oligotrophic conditions, and with lower risk of $\mathrm{NO}_{2}^{-}$pollution, than DNP populations. 
Table 1

Summary of the experimental setup in each bioassay (DNP - Doñana Natural Park; GM - Gredos Mountain) and corresponding average temperatures registered, and results of

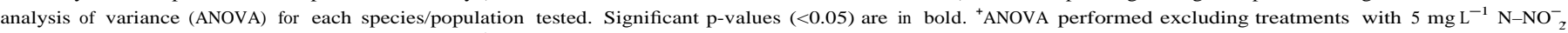

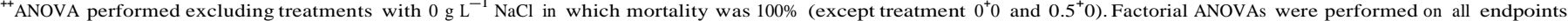
with the exception of body length of $\mathrm{H}$. meridionalis.

\begin{tabular}{|c|c|c|c|c|c|c|}
\hline Species $\left({ }^{\mathrm{a}}\right)$ & Exposure concentrations ${ }^{\mathrm{b}}$ & Variable & Effect & F & $\begin{array}{l}\text { d.f. (effect, } \\
\text { error) }\end{array}$ & $\mathrm{p}$ \\
\hline \multirow[t]{6}{*}{ B. calamita (DNP, 14 larvae, 25, $21.78 \pm 0.74$ ) } & \multirow[t]{6}{*}[0,0.1,0.25,0.5,1,2.5,5,7.5]{$\times\{0,0.4,2\}$} & \multirow[t]{3}{*}{ Activity rate } & $\mathrm{NaNO}_{2}$ & 1.894 & 7,48 & 0.091 \\
\hline & & & $\mathrm{NaCl}$ & 11.067 & 2,48 & 0.000 \\
\hline & & & $\mathrm{NaNO}_{2} \times \mathrm{NaCl}$ & 0.806 & 14,48 & 0.658 \\
\hline & & \multirow[t]{3}{*}{ Mortality rate } & $\mathrm{NaNO}_{2}$ & 0.242 & 7,48 & 0.973 \\
\hline & & & $\mathrm{NaCl}$ & 9.939 & 2,48 & 0.000 \\
\hline & & & $\mathrm{NaNO}_{2} \times \mathrm{NaCl}$ & 0.863 & 14,48 & 0.602 \\
\hline \multirow[t]{5}{*}{ H. meridionalis (DNP, 11 larve, $25,17.54 \pm 0.83$ ) } & \multirow[t]{5}{*}[0,5,15]{$\times\{0,0.4,2\}$} & \multirow[t]{2}{*}{ Body lengtb } & $\mathrm{NaNO}_{2}$ & 1.211 & 2,8 & 0.347 \\
\hline & & & $\mathrm{NaCl}$ & 3.091 & 1,9 & 0.113 \\
\hline & & \multirow[t]{3}{*}{ Mortality rate (day 15) } & $\mathrm{NaNO}_{2}$ & 0.500 & 2,18 & 0.615 \\
\hline & & & $\mathrm{NaCl}$ & 2.000 & 2,18 & 0.164 \\
\hline & & & $\mathrm{NaNO}_{2} \times \mathrm{NaCl}$ & 0.500 & 4,18 & 0.736 \\
\hline \multirow[t]{9}{*}{ P. perezi (DNP, 12 eggs, $14-18,18.00 \pm 0.80$ ) } & \multirow[t]{9}{*}[0,5,15]{$\times\{0,0.4,2\}$} & \multirow[t]{3}{*}{ Hatching rate at day 5} & $\mathrm{NaNO}_{2}$ & 1.230 & 2,18 & 0.316 \\
\hline & & & $\mathrm{NaCl}$ & 4.595 & 2,18 & 0.024 \\
\hline & & & $\mathrm{NaNO}_{2} \times \mathrm{NaCl}$ & 1.127 & 4,18 & 0.375 \\
\hline & & \multirow[t]{3}{*}{ Body length } & $\mathrm{NaNO}_{2}$ & 18.981 & 1,16 & 0.000 \\
\hline & & & $\mathrm{NaCl}$ & 4.596 & 1,16 & 0.048 \\
\hline & & & $\mathrm{NaNO}_{2} \times \mathrm{NaCl}$ & 12.696 & 3,16 & 0.000 \\
\hline & & \multirow[t]{3}{*}{ Mortality rate } & $\mathrm{NaNO}_{2}$ & 37.892 & 2,18 & 0.000 \\
\hline & & & $\mathrm{NaCl}$ & 62.167 & 2,18 & 0.000 \\
\hline & & & $\mathrm{NaNO}_{2} \times \mathrm{NaCl}$ & 27.832 & 4,18 & 0.000 \\
\hline \multirow[t]{15}{*}{ P. perezi (GM, 19 eggs, $18-19,14.58 \pm 1.32$ ) } & \multirow[t]{15}{*}[0,1,2.5,5]{$\times\{0,0.052,0.2\}$} & \multirow[t]{3}{*}{ Hatching rate day 7} & $\mathrm{NaNO}_{2}$ & 1.089 & 3,24 & 0.373 \\
\hline & & & $\mathrm{NaCl}$ & 1.377 & 2,24 & 0.272 \\
\hline & & & $\mathrm{NaNO}_{2} \times \mathrm{NaCl}$ & 0.718 & 6,24 & 0.639 \\
\hline & & \multirow[t]{3}{*}{ Abnormality rate } & $\mathrm{NaNO}_{2}$ & 11.750 & 3,24 & 0.000 \\
\hline & & & $\mathrm{NaCl}$ & 39.473 & 2,24 & 0.000 \\
\hline & & & $\mathrm{NaNO}_{2} \times \mathrm{NaCl}$ & 6.227 & 6,24 & 0.000 \\
\hline & & \multirow[t]{3}{*}{ Activity rate } & $\mathrm{NaNO}_{2}$ & 35.271 & 3,24 & 0.000 \\
\hline & & & $\mathrm{NaCl}$ & 77.408 & 2,24 & 0.000 \\
\hline & & & $\mathrm{NaNO}_{2} \times \mathrm{NaCl}$ & 8.401 & 6,24 & 0.000 \\
\hline & & \multirow[t]{3}{*}{ Total length ${ }^{++}$} & $\mathrm{NaNO}_{2}$ & 0.290 & 3,14 & 0.832 \\
\hline & & & $\mathrm{NaCl}$ & 0.128 & 1,14 & 0.726 \\
\hline & & & $\mathrm{NaNO}_{2} \times \mathrm{NaCl}$ & 0.746 & 3,14 & 0.542 \\
\hline & & \multirow[t]{3}{*}{ Mortality rate } & $\mathrm{NaNO}_{2}$ & 3.617 & 3,24 & 0.027 \\
\hline & & & $\mathrm{NaCl}$ & 23.713 & 2,24 & 0.000 \\
\hline & & & $\mathrm{NaNO}_{2} \times \mathrm{NaCl}$ & 1.519 & 6,24 & 0.215 \\
\hline
\end{tabular}

\footnotetext{
${ }^{\text {a }}$ Origin, $\mathrm{N}^{\circ}$ of individuals per replica, Gosner stage at day 0 of exposure, Average temperature $\left({ }^{\circ} \mathrm{C}\right) \pm \mathrm{St}$. dev.
}

b $\left[\mathrm{NaNO}_{2} \mathrm{mg} \mathrm{L}^{-1} \mathrm{~N}-\mathrm{NO}_{2}^{-}\right] \times\left\{\mathrm{NaCl} \mathrm{g} \mathrm{L}{ }^{-1}\right\}$.

\subsection{Experimental animals and exposure data}

Newly-hatched Bufo calamita larvae were gathered once from a temporary pond in Puebla del Río (DNP; altitude 20; N37 $12^{\circ} 17^{0}$, $\left.W 6^{\circ} 10^{\circ} 6^{\infty}\right)$ in March 2005. The tadpoles were transported to the Limnology laboratory in Seville University. Eight concentrations of sodium nitrite $\left(\mathrm{NaNO}_{2} ; 0,0.1,0.25,0.5,1.0,2.5,5.0\right.$ and $7.5 \mathrm{mg} \mathrm{L}^{-1} \mathrm{~N}-\mathrm{NO}_{2}^{-}$) were crossed with three concentrations of $\mathrm{NaCl}$ (0, 0.4 and $\left.2 \mathrm{~g} \mathrm{~L}^{-1} \mathrm{NaCl}\right)$, a total of 24 different treatments. Fourteen tadpoles at Gosner (1960) stage 25 were randomly allocated to three replicates of each treatment and were exposed for $15 \mathrm{~d}$. See Table 1 for setup details of all bioassays. The B. calamita bioassay was performed previously to all other bioassays. As such, and given a particular local abundance of larvae, a broader range of $\mathrm{NaNO}_{2}$ concentrations were tested. The selected concentrations were based on previous reports on the toxicity of $\mathrm{NO}_{2}^{-}$to larval amphibians (Huey and Beitinger, 1980a, 1980b; Marco and Blaustein, 1999; Marco et al., 1999; Griffis-Kyle, 2005). Larvae/eggs for subsequent bioassays with other amphibian species were not as abundant in the wild, leading to a smaller range of treatments in order to maintain replicate numbers to a minimum of three. Not all species were tested starting from the same life stage as the availability of organisms was restricted to the moment at which the clutches were found in the field. With the objective of exposing organisms from the earliest stage possible, the stage at which the clutches were found at in the field determined the stage at which they were at upon the start of the test.

Hyla meridionalis larvae and P. perezi eggs were gathered from

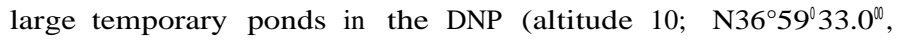
W6 $\left.6^{\circ} 6^{0} 57.9^{\infty}\right)$ in April 2005 and transported to the El Bolín laboratory (DNP). Three replicates of $12 \mathrm{P}$. perezi eggs and eleven $\mathrm{H}$. meridionalis Gosner (1960) stage 25 larvae were exposed separately to $\mathrm{NaNO}_{2}$ concentrations of 0,5 and $15 \mathrm{mg} \mathrm{L}^{-1} \mathrm{~N}-\mathrm{NO}_{2}^{-}$ crossed with three concentrations of $\mathrm{NaCl}\left(0,0.4\right.$ and $\left.2 \mathrm{~g} \mathrm{~L}^{-1} \mathrm{NaCl}\right)$, during $15 \mathrm{~d}$. Given that low mortality occurred at $7.5 \mathrm{mg} \mathrm{L}^{-1} \mathrm{~N}-$ $\mathrm{NO}_{2}^{-}$in the previously conducted $\mathrm{B}$. calamita bioassay, we chose to expose DNP larvae to higher $\mathrm{NO}_{2}^{-}$concentrations.

P. perezi egg masses were gathered from a temporary pond in the Sierra de Gredos Mountain (GM; altitude 1910; N40 $16^{\circ} 34.7^{0}$, $\mathrm{W} 5^{\circ} 14^{0} 14.5^{\circ}$ ) in June 2005 and were transported to the field station at the same altitude. Equal numbers of eggs from each clutch were distributed between each replicate of four concentrations of 
$\mathrm{NaNO}_{2}\left(0,1.0,2.5\right.$ and $\left.5.0 \mathrm{mg} \mathrm{L^{-1 }} \mathrm{N}-\mathrm{NO}_{2}^{-}\right)$crossed with three concentrations of $\mathrm{NaCl}\left(0,0.052\right.$ and $\left.0.2 \mathrm{~g} \mathrm{~L}^{-1} \mathrm{NaCl}\right)$. Since we suspected that the GM population would be more sensitive to the presence of $\mathrm{NO}_{2}^{-}$(Shinn et al., 2008) and $\mathrm{NaCl}$ (due to very low conductivity of GM water), the exposure media in this bioassay covered a range of lower concentrations than in the bioassays performed with the DNP specimens. Larvae were exposed to the chemicals for $16 \mathrm{~d}$.

Hereafter and when appropriate, treatment combinations will be abbreviated as $\left[\mathrm{N}-\mathrm{NO}_{2}^{-}\right]^{+}[\mathrm{NaCl}]\left(\mathrm{mg} \mathrm{L}^{-1}\right.$ and $\mathrm{g} \mathrm{L}^{-1}$, respectively).

\subsection{Experimental design}

Opaque plastic cups were used as holding tanks, each containing $0.5 \mathrm{~L}$ of prepared exposure solution. Each holding tank corresponded to individual experimental units (replicates). Concentrated stock solutions of $0.245 \mathrm{~g} \mathrm{~L}^{-1} \mathrm{NaNO}_{2}$ and $10 \mathrm{~g} \mathrm{~L}^{-1} \mathrm{NaCl}$ were used to prepare the various diluted exposure media. Dilution water was taken from a well at the El Bolín laboratory and from a local mountain spring for the bioassays carried out in Seville/DNP and GM, respectively. Holding tanks were kept under conditions of natural photoperiod and lighting coming from windows. Water samples were taken every other day to monitor $\mathrm{NO}_{2}^{-}$concentrations. The Shinn method (Shinn, 1941) was used to determine the concentration of $\mathrm{NO}_{2}^{-}$in each sample spectrophotometrically (Hitachi U-1000 ${ }^{\circledR}$ ). Samples taken during the bioassays conducted at El Bolín laboratory and at the field station in GM were stabilized by adding chloroform, and were stored in a cool, dark place until analysis (maximum 4 weeks after sampling). At the midpoint of each bioassay the media were replaced with fresh solutions of the initial concentrations. Dissolved oxygen (Hanna HI 9142 ${ }^{\circledR}$ ), pH (Hanna HI 99100 ${ }^{\circledR}$ ) and conductivity (Hanna HI 9033 Multi-range ${ }^{\circledR}$ ) of the water of all tanks were measured every other day. $\mathrm{NaCl}$ concentrations were estimated directly from conductivity readings. Two Data Loggers ${ }^{\circledR}$, placed in separate individual tanks with $0.5 \mathrm{~L}$ of water, registered the temperature at $30 \mathrm{~min}$ intervals throughout each bioassay (Table 1). Tadpoles were fed boiled lettuce ad libitum.

To evaluate the effect of the different $\mathrm{NaNO}_{2}^{+} \mathrm{NaCl}$ treatments on the exposed larvae, the number of hatched embryos, dead larvae, and abnormalities (edemas and spinal anomalies), as well as the activity of the larvae (number of individuals in the water column), was registered daily throughout the experimental period. Rates were calculated by dividing the data by the total number of live individuals at the time of observation. Dead larvae and excess organic waste were removed daily to avoid oxygen depletion. At the end of each bioassay (except for the B. calamita bioassay), photos of the surviving tadpoles were taken by placing them on a Petri dish with millimetric paper as a reference scale. The photos were then digitally analyzed using ArcView $3.2^{\circledR}$ to determine the size of the tadpoles after each treatment (body length: tip of head to cloaca; total length: tip of head to tip of tail). Lengths were used to assess differences in tadpole size between treatments, assuming that all individuals within each bioassay had similar size at the start.

\subsection{Statistical analysis}

The ARCSIN transformed data for mortality, hatching, activity and abnormality rates, and non-transformed data for larvae size, conformed to assumptions for parametric analysis. Analyses of variance (ANOVA) were performed to assess the effect of $\mathrm{NaNO}_{2}, \mathrm{NaCl}$, and their interaction, on the variables measured for each species. Data considered were from the last day (day 15/16) for mortality and abnormality rates, and from day 5 to 8 for hatching rates. In the case of $\mathrm{H}$. meridionalis body length, there were not enough degrees of freedom to perform a factorial ANOVA, thus single oneway ANOVAs for each factor were conducted. Post hoc Tukey tests were performed in order to assess which exposure treatments were significantly different from one another. All statistical analyses were carried using STATISTICA (ver. 10, 2010, Stat Soft Inc.) with a significant probability level of $\mathrm{p}<0.05$.

\section{Results}

\subsection{Water physical and chemical conditions}

$\mathrm{NO}_{2}^{-}$concentrations in the experimental tanks stayed within $20 \%$ of the nominal concentrations. Exceptions were the 0.1, 0.25 and $0.5 \mathrm{mg} \mathrm{L}^{-1} \mathrm{~N}-\mathrm{NO}_{2}^{-}$treatments in the B. calamita bioassay in which $\mathrm{NO}_{2}^{-}$concentrations deviated almost $50 \%$ below nominal concentrations. This deviation was possibly the result of an error in the analytical procedure or the occurrence of $\mathrm{NO}_{2}^{-}$reduction via bacterial or algal activity, possibly potentiated by a low renewal rate of exposure solution. $\mathrm{NO}_{2}^{-}$background concentrations of the dilution water used in the bioassays were between 0.000 and $0.021 \mathrm{mg} \mathrm{L}^{-1} \mathrm{~N}-\mathrm{NO}_{2}^{-}$. Test water dissolved oxygen levels remained above $70 \%$ and $\mathrm{pH}$ and conductivity remained stable throughout the experimental period. The test water from GM had lower background $\mathrm{pH}$ (5.6-6.7) and conductivity $\left(15 \mathrm{IS} \mathrm{cm}^{-1}\right)$ than the water from DNP (8.0-8.2; $\left.4221 \mathrm{Is} \mathrm{cm}^{-1}\right)$. In general, average water conditions remained within the natural ranges of the respective breeding sites. The water temperature during the DNP bioassays was considerably higher (in average $4-7{ }^{\circ} \mathrm{C}$ higher), and with less variation throughout each bioassay than in GM (Table 1).

\subsection{Effect of $\mathrm{NaNO}_{2}$ and $\mathrm{NaCl}$ on larvae}

\subsubsection{B. Calamita, DNP}

B. calamita larvae mortality and activity rates were significantly affected by the presence of $\mathrm{NaCl}$ but not by the presence of $\mathrm{NaNO}_{2}$ or both combined (Table 1 ).

Control $\left(0^{+} 0\right)$ B. calamita experienced low mortality rates $(0-14 \%)$ except in one of the replicates in which there occurred $71 \%$ mortality at day 11. We were not able to identify the causes of this interreplicate variability and given that control mortality rates were above $10 \%$, this assay was not considered valid (ASTM guideline E729, 2007). After $11 \mathrm{~d}$ of exposure there was considerable lower mortality rate in treatments with $2 \mathrm{~g} \mathrm{~L}^{-1} \mathrm{NaCl}$ than controls and treatments with $0.4 \mathrm{mg} \mathrm{L}^{-1} \mathrm{~N}-\mathrm{NO}_{2}^{-}$. Punctual mortality (between 36\% and 85\%) occurred throughout the exposure in one replicate of treatments with $0 \mathrm{~g} \mathrm{~L}^{-1} \mathrm{NaCl}$ and $0.1,1,5$, and $7.5 \mathrm{mg} \mathrm{L}^{-1} \mathrm{~N}-\mathrm{NO}_{2}^{-}$. All other replicates and treatments had low mortality rates (average $=7 \%$ ).

\subsubsection{H. meridionalis, DNP}

The presence of $\mathrm{NaNO}_{2}, \mathrm{NaCl}$, or both combined did not induce any effect among the $\mathrm{H}$. meridionalis larvae (Table 1 ).

\subsubsection{P. perezi, DNP}

The presence of $\mathrm{NaCl}, \mathrm{NaNO}_{2}$ and both combined significantly affected the final body length and mortality rate of DNP P. perezi larvae, and $\mathrm{NaCl}$ alone affected hatching rate (Table 1 ).

DNP P. perezi larvae hatched later in $\mathrm{NaNO}_{2}$ treatments without $\mathrm{NaCl}$, a $1 \mathrm{~d}$ delay in comparison to those in the presence of $\mathrm{NaCl}$. By the end of the bioassay, P. perezi larvae from DNP presented between $0.0 \%$ and $0.1 \%$ mortality in treatments with 0 or $5 \mathrm{mg} \mathrm{L}^{-1}$ $\mathrm{N}-\mathrm{NO}_{2}^{-}$, at the different concentrations of $\mathrm{NaCl} .100 \%$ mortality in the $15^{+} 0$ treatment occurred after $13 \mathrm{~d}$ of exposure, thus resulting in a significantly different effect of this treatment in comparison to all others (post-hoc Tukey test). Concentrations of 2 and $0.4 \mathrm{~g} \mathrm{~L}^{-1}$ $\mathrm{NaCl}$ reduced this mortality rate to practically zero.

Larvae that were exposed to the $5+0$ treatment presented significantly smaller final body lengths than in other treatments 

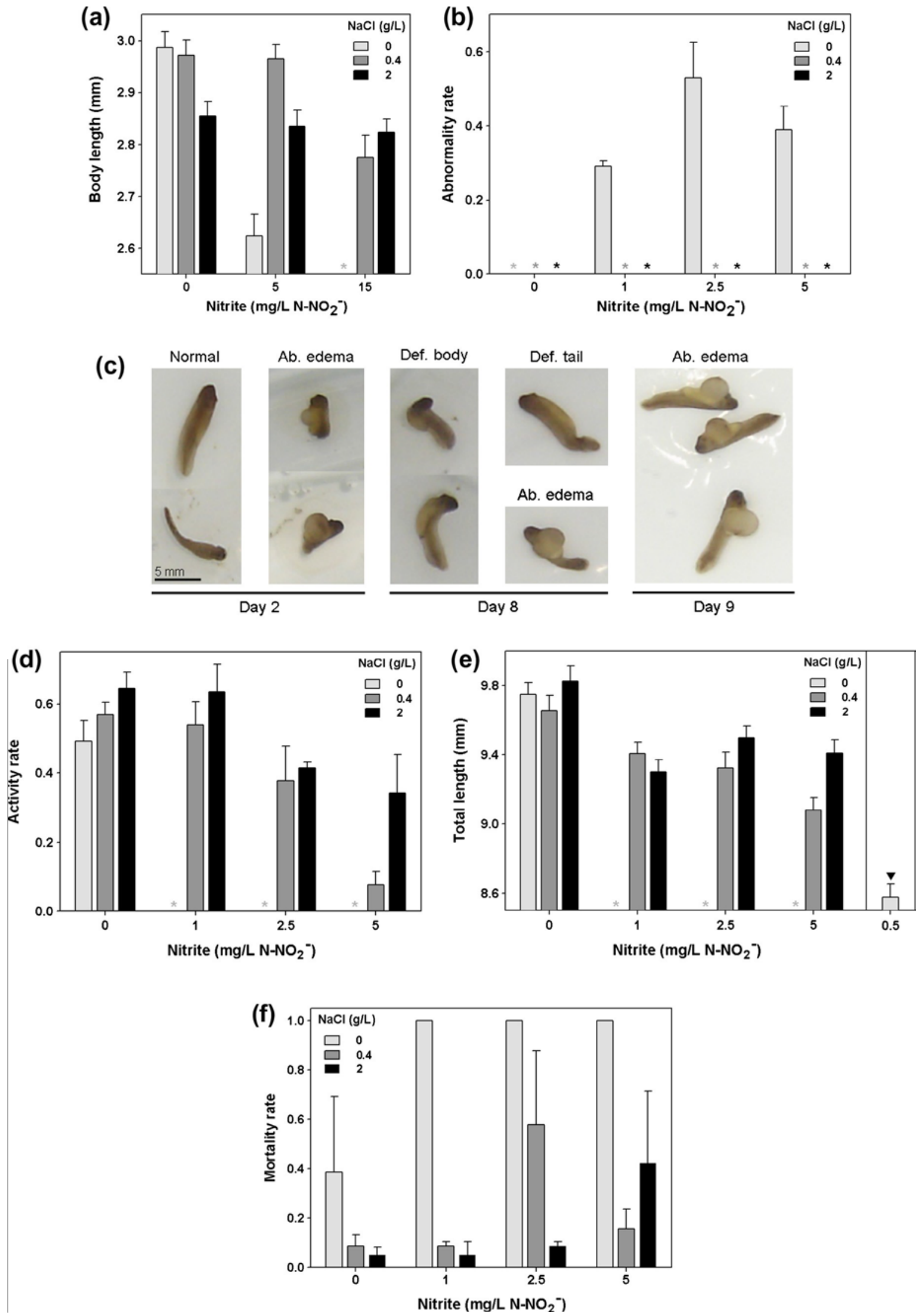

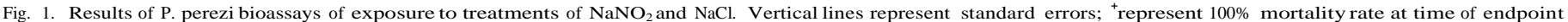

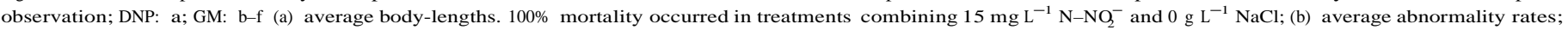

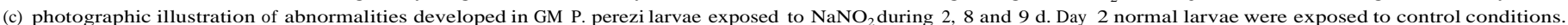

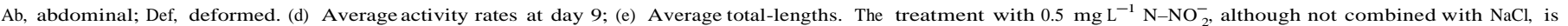
added to the graph for comparison ( _ , data from Shinn et al., 2008); and (f) average mortality rates. 
(Fig. 1a). In average, larvae grew significantly more in $0+0,0+0.4$ and 5+0.4. Without $\mathrm{NaCl}$ larvae either did not survive the presence of $\mathrm{NO}_{2}^{-}\left(15 \mathrm{mg} \mathrm{L}^{-1} \mathrm{~N}-\mathrm{NO}_{2}^{-}\right)$or grew $12 \%$ less $\left(5 \mathrm{mg} \mathrm{L}^{-1} \mathrm{~N}-\mathrm{NO}_{2}^{-}\right)$ than controls. Larvae developing in $\mathrm{NaCl}$ at $2 \mathrm{~g} \mathrm{~L}^{-1}$ presented equivalent size regardless of the $\mathrm{NaNO}_{2}$ treatment, whilst those developing in the $15+0.4$ treatment were $6.5 \%$ smaller than those in $0+0.4$ and $5+0.4$.

\subsubsection{P. perezi, GM}

GM P. perezi abnormality and activity rates were significantly affected by the simultaneous presence of $\mathrm{NaCl}$ and $\mathrm{NaNO}_{2}$ (Table 1). Post-hoc Tukey tests indicated that, for both of these endpoints, treatments of $0 \mathrm{~g} \mathrm{~L}^{-1} \mathrm{NaCl}$ with $\mathrm{NaNO}_{2}$ are significantly different from the rest of treatments of $\mathrm{NaCl}$ both with and without $\mathrm{NaNO}_{2}$.

There was a higher abnormality rate in treatments with $\mathrm{NaNO}_{2}$ in the absence of $\mathrm{NaCl}$ (Fig. $1 \mathrm{~b}$ and c), observed before and after hatching. Larvae exposed to $\mathrm{NaNO}_{2}$ but no $\mathrm{NaCl}$ showed a significantly reduced activity level after $9 \mathrm{~d}$ of exposure (Fig. 1d).

P. perezi eggs from GM exposed to higher concentrations of $\mathrm{NaCl}$ (e.g. $0.2 \mathrm{~g} \mathrm{~L}^{-1}$ ) contained embryos with more accentuated spinal anomalies (body curvature). The jelly of those eggs seemed to be contracted, with a smaller diameter in comparison to those exposed to lower concentrations of $\mathrm{NaCl}$. However, after hatching the larvae were as active as those that had not suffered spinal anomalies. This curvature was not observed in DNP P. perezi embryos (which were exposed to higher $\mathrm{NaCl}$ concentrations).

The lack of statistically significant effects on GM P. perezi growth is due to the absence of data on tadpole length at $0 \mathrm{~g} \mathrm{~L}^{-1}$ $\mathrm{NaCl}$ in most $\mathrm{NaNO}_{2}$ treatments, resulting from $100 \%$ mortality rates in those treatments. However, GM P. perezi larvae exposed to $0.5^{+} 0$ grew much less than all the other larvae that also survived the $16 \mathrm{~d}$ exposure period (Fig. 1e).

When exposed simultaneously to $\mathrm{NaNO}_{2}$ and low concentrations of $\mathrm{NaCl}$, the mortality rates of GM P. perezi larvae were greatly decreased. In $1^{+} 0,2.5^{+} 0$ and $5^{+} 0$ treatments, mortality rates of $90 \%$ and $100 \%$ were observed, significantly higher than in controls and treatments with 0.052 and $0.2 \mathrm{~g} \mathrm{~L}^{-1} \mathrm{NaCl}$ (Fig. 1b). These interactions were not statistically significant mainly due to a strong variability among replicates in the control treatment $\left(0^{+} 0\right.$; Fig. 1f), i.e. one replicate tank with high mortality but others with low mortality.

\section{Discussion}

The toxicity of $\mathrm{NO}_{2}^{-}$to larval amphibians was strongly attenuated by the presence of a range of $\mathrm{NaCl}$ concentrations. This effect was especially apparent in the bioassays with $\mathrm{P}$. perezi. In comparison to $\mathrm{NO}_{2}^{-}$treatments without $\mathrm{NaCl}, \mathrm{P}$. perezi larvae exposed to $\mathrm{NO}_{2}^{-}$treatments with $\mathrm{NaCl}$ presented: increased larval activity and body size, and reduced mortality and abnormality rates. These observations corroborate the hypothesis that $\mathrm{Cl}^{-}$ions reduce the toxicity of $\mathrm{NO}_{2}^{-}$, observed in studies on amphibians, fish and invertebrates (Huey and Beitinger, 1980a,b; Lewis and Morris, 1986; Alonso and Camargo, 2008). In the presence of $\mathrm{NO}_{2}^{-}$, reduced activity and abnormal features may result in higher predation risk and hinder success upon metamorphosis (Ortiz-Santaliestra et al., 2010b). As seen in the present study, the presence of $\mathrm{Cl}^{-}$ions helps the $\mathrm{NO}_{2}^{-}$-exposed larvae to overcome these adverse effects and, in some situations, to survive. Furthermore, abnormalities appeared in GM embryos still within the gelatinous egg when exposed to $\mathrm{NO}_{2}^{-}$but no $\mathrm{NaCl}$ (Fig. 1c). This indicates that $\mathrm{NO}_{2}^{-}$can have deleterious effects even before the larvae have hatched: $\mathrm{NaCl}$ can protect larval amphibians from $\mathrm{NO}_{2}^{-}$early on in their development.

The natural water conductivity of the respective breeding ponds, from where the eggs and larvae were collected, is not high enough to protect larval amphibians from high or moderate (the maximum tested in the present study) $\mathrm{NO}_{2}^{-}$concentrations, especially in GM. An increase of $\mathrm{NO}_{2}^{-}$concentrations in mountain surface waters is rare but for field fertilization, fires, or the presence of livestock in the summer. On the contrary, the lowland DNP ponds may experience peaks of both $\mathrm{NO}_{2}^{-}$and salinity (Serrano et al., 2006). The higher sensitivity of P. perezi from GM to the presence of $\mathrm{NO}_{2}^{-}$, in comparison to $\mathrm{P}$. perezi from DNP, may be related to the differences in the respective natural mineral contents of the breeding ponds. Background conductivity in the test water in GM was very low, just above the range of distilled water (0.5$51 \mathrm{~s} \mathrm{~cm}^{-1}$ ), whilst that of the water from El Bolín laboratory (DNP) was within the limits for freshwater environments (<3000 Is cm $\mathrm{cm}^{-1}$; Wetzel, 2001). The low conductivity in GM is most probably due to the fact that the main water source at that altitude is the thawing of ice and snow. DNP ponds and lakes register a variety of salinity levels (freshwater to brackish) that vary according to the season of the year and distance to the coastal wetlands (Serrano et al., 2006). Amphibian populations in DNP may have undergone adaptation to the varying (higher) levels of salinity throughout their evolutionary history. Indeed, by performing common garden experiments, Gomez-Mestre and Tejedo (2003) observed local adaptation to salinity in B. calamita from brackish and freshwater ponds in DNP. In their study, the freshwater B. calamita population presented lower salinity tolerance than the brackish water population. Licht et al. (1975) observed that Batrachoseps relictus salamander populations living closer to sea water were more resistant to salinity levels than populations. Furthermore, prior acclimation to intermediate salinities improved B. relictus tolerance to high salinities. Ortiz-Santaliestra et al. (2010a) concluded that $\mathrm{P}$. perezi embryos adapted to osmotic stress conferred protection against ammonium nitrate toxicity. In our study, GM P. perezi, being less accustomed to higher salinity levels like those found in DNP waters, responded in a stronger manner (in comparison to the DNP population) to the beneficial presence of $\mathrm{NaCl}$ when exposed to adverse $\mathrm{NO}_{2}^{-}$concentrations. However, we can only suggest, not confirm, local adaptation because temperature varied among the different experiments.

A similar rationale can be followed for explaining why the natural $\mathrm{NO}_{2}^{-}$tolerance of $\mathrm{GM} P$. perezi is lower than DNP $\mathrm{P}$. perezi. Egea-Serrano et al. (2009) hypothesized that P. perezi populations from areas impacted by agricultural pollution for the last 30 years have undergone local adaptation to nitrogen contamination. DNP ponds presented higher background concentrations of $\mathrm{NO}_{2}^{-}$than GM ponds, thus the local amphibian populations are possibly more resistant (adapted) to increases in $\mathrm{NO}_{2}^{-}$concentrations. The observed difference in the beneficial effect of $\mathrm{NaCl}$ between populations of the same species may indicate the existence of a threshold, at which the increase of $\mathrm{NaCl}$ will no longer protect the organism from $\mathrm{NO}_{2}^{-}$toxicity due to the species' (or population's) tolerance to the concentrations of $\mathrm{NaCl}$ per se. This was apparent in the GM P. perezi bioassay in which the higher the concentration of $\mathrm{NaNO}_{2}$, the weaker became the beneficial presence of $\mathrm{NaCl}$.

\section{Conclusions}

Amphibians are common in many agricultural landscapes but are threatened by $\mathrm{NO}_{2}^{-}$runoff from the widespread use of nitrogen-based fertilizers (Marco et al., 1999; Griffis-Kyle, 2005). In the light of our results, it would be expected to find a reduced impact of $\mathrm{NO}_{2}^{-}$exposure in areas where natural $\mathrm{Cl}^{-}$ concentrations are higher. The extent of the $\mathrm{Cl}^{-}$-protection also depends on the species and its innate tolerance to $\mathrm{NO}_{2}^{-}$and environmental perturbations in general. Furthermore, not all species may present the same response - or any at all - to the beneficial effect of the presence of $\mathrm{Cl}^{-}$in the case of increase of $\mathrm{NO}_{2}^{-}$. 
In the coastal marshland of the Doñana Natural Park there is a strong debate concerning the use of brackish water to control the invasion of some exotic aquatic plants and pathogenic bacteria. In addition, agricultural activity per se also increases water salinity as a result of the shallow rooting systems of predominant crops that are less effective in retaining nutrients and minerals (Hart et al., 2003; Ortiz-Santaliestra et al., 2010a). Upon an increase in $\mathrm{NO}_{2}^{-}$concentrations in the water bodies, a more tolerant aquatic species could benefit from an increase in water salinity; other species would suffer the direct impact of either or both stressors synergistically, as demonstrated by Ortiz-Santaliestra et al. (2010a). Furthermore, coastal wetlands are generally characterized by strong temporal and spatial gradients of salinity. Amphibian and other aquatic organism populations that inhabit higher salinity environments and that are recurrently exposed to nitrogen pollution could, over time, become adapted to the prevailing conditions. More sensitive individuals are likely to be selectively eliminated, especially when additional stressors due to strong fluctuations in habitat conditions (e.g. rain events that alter water parameters) are combined with the presence of contaminants.

The present study is, to our knowledge, the first to demonstrate the protecting effect of $\mathrm{NaCl}$ against $\mathrm{NO}_{2}^{-}$toxicity in anuran species with internal gills. Our findings may have important implications in the rearing of amphibians (and of other freshwater aquatic organisms) in captivity for commercial, research, conservation, and re-introduction purposes. In aquaculture, especially of freshwater fish, calculated quantities of $\mathrm{NaCl}$ are added to the water in order to increase environmental concentrations of $\mathrm{Cl}^{-}$ions to deal with problems related to $\mathrm{NO}_{2}^{-}$build-up (Francis-Floyd, 1995). A similar practice could be implemented in frog hatcheries for commercial, research or conservation purposes, so long as the species' salt tolerance is well known.

Given that amphibian species tend to avoid inhabiting and breeding in saline and brackish areas and often lack efficient osmoregulation mechanisms (McDiarmid and Altig, 1999), it is generally accepted that the less salty an aquatic environment, the better for amphibians (Gomez-Mestre and Tejedo, 2003). However, this may not always be the case. Indeed, although amphibians are mostly freshwater dwellers, very low concentrations of $\mathrm{Cl}^{-}$(salinity) may have an uncalculated beneficial effect when the environment is contaminated with $\mathrm{NO}_{2}^{-}$and under certain circumstances. Further studies are called for in order to reveal other species for which salinity can help resist $\mathrm{NO}_{2}^{-}$increases, and why it is so for some species but not for others.

\section{Acknowledgments}

The authors wish to thank Guadalupe Macías and Luca Moura for their practical assistance and Jennifer Sneddon for comments on previous drafts of the present article. This study was funded by the Spanish Ministry of Education and Science.

\section{References}

Alonso, A., Camargo, J.A., 2004. Toxic effects of unionized ammonia on survival and feeding activity of the freshwater amphipod Eulimnogammarus toletanus (Gammaridae, Crustacea). Bull. Environ. Contam. Toxicol. 72, 1052-1058.

Alonso, A., Camargo, J.A., 2008. Ameliorating effect of chloride on nitrite toxicity to freshwater invertebrates with different physiology: a comparative study between amphipods and planarians. Arch. Environ. Contam. Toxicol.54, 259265.

ASTM Standard E729, 2007. Standard Guide for Conducting Acute Toxicity Tests on Test Materials with Fishes, Macroinvertebrates, and Amphibians. ASTM International, West Conshohocken, PA. http://dx.doi.org/10.1520/E072996R07, <www.astm.org>.

Bath, R.N., Eddy, F.B., 1980. Transport of nitrite across fish gills. J. Exp. Zool. 214, 119-121.

Blaustein, A.R., Romansic, J., Kiesecker, J., Hatch, A., 2003. Ultraviolet radiation, toxic chemicals and amphibian population declines. Divers. Distrib. 9, 123-140.
Bogardi, I., Kuzelka, R.D., Ennenga, W.G., 1991. Nitrate Contamination: Exposure Consequence and Control NATO ASI Series G-Ecological Sciences, vol. 30. Springer, Verlag, New York, NY, USA.

Carpenter, S.R., Bolgrien, D., Lathrop, R.C., Stowe, C.A., Reed, T., Wilson, M.A., 1997. Ecological and economic analysis of lake eutrophication by nonpoint pollution. Aust. J. Ecol. 23, 68-79.

Crawford, R.E., Allen, G.H., 1977. Seawater inhibition of nitrite toxicity to chinook salmon. Trans. Am. Fish Soc. 106, 105-109.

Egea-Serrano, A., Tejedo, M., Torralva, M., 2009. Populational divergence in the impact of three nitrogenous compounds and their combination on larvae of the frog Pelophylax perezi (Seoane, 1885). Chemosphere 76, 869-877.

Francis-Floyd, R., 1995. The Use of Salt in Aquaculture. Fact Sheet VM86. Department of Large Animal Clinical Sciences. University of Florida.

Gomez-Mestre, I., Tejedo, M., 2003. Local adaptation of an anuran amphibian to osmotically stressful environments. Evolution 57, 1889-1899.

Gosner, K.L., 1960. A simplified table for staging anuran embryos and larvae with notes on identification. Herpetologica 16, 183-190.

Griffis-Kyle, K.L., 2005. Ontogenic delays in effects of nitrite exposure on tiger salamanders (Ambystoma tigrinum tigrinum) and wood frogs (Rana sylvatica). Environ. Toxicol. Chem. 24, 1523-1527.

Hart, B.T., Lake, P.S., Webb, J.A., Grace, M.R., 2003. Ecological risk to aquatic systems from salinity increases. Aust. J. Bot. 51, 689-702.

Huey, D.W., Beitinger, T.L., 1980a. Hematological responses of larval Rana catesbeiana to sublethal nitrite exposures. Bull. Environ. Contam. Toxicol. 25, 574-577.

Huey, D.W., Beitinger, T.L., 1980b. Toxicity of nitrite to larvae of the salamander Ambystoma texanum. Bull. Environ. Contam. Toxicol. 25, 909-912.

Lewis Jr., W.M., Morris, D.P., 1986. Toxicity of nitrite to fish: a review. Trans. Am. Fish Soc. 115, 183-195.

Licht, P., Feder, M., Bledsoe, S., 1975. Salinity tolerance and osmoregulation in the salamander Batrachoseps. J. Comp. Physiol. B. Biochem. Syst. Environ. Physiol. 102, 123-134.

Lizana, M., Pedraza, E.M., 1998. Different mortality of toad embryos (Bufo bufo and Bufo calamita) caused by UV-B radiation in high mountain areas of the Spanish Central System. Conservation Biol. 12, 703-707.

Marco, A., Blaustein, A.R., 1999. The effects of nitrite on behavior and metamorphosis in Cascades Frogs (Rana cascadae). Environ. Toxicol. Chem. 18, 946-949.

Marco, A., Ortiz-Santaliestra, M.E., 2009. Pollution: impact of reactive nitrogen on amphibians. In: Heatwole, H., Wilkinson, J.W. (Eds.), Amphibian Biology, Amphibian Decline: Diseases, Parasites, Maladies and Pollution, vol. 8. Surrey Beatty \& Sons, Baulkham Hills, pp. 3145-3185

Marco, A., Quilchano, C., Blaustein, A.R., 1999. Sensitivity to nitrate and nitrite in some pond-breeding amphibians from the Pacific Northwest. Environ. Toxicol. Chem. 18, 2836-2839.

McDiarmid, R.W., Altig, R., 1999. Tadpoles - The Biology of Anuran Larvae. The University of Chicago Press, Chicago.

Ortiz-Santaliestra, M.E., Marco, A., Fernández, M.J., Lizana, M., 2006. Influence of developmental stage on sensitivity to ammonium nitrate of aquatic stages of amphibians. Environ. Toxicol. Chem. 25, 105-111.

Ortiz-Santaliestra, M., Fernández-Benéitez, M.J., Lizana, M., Marco, A., 2010a. Adaptation to osmotic stress provides protection against ammonium nitrate in Pelophylax perezi embryos. Environ. Pollut. 158, 934-940.

Ortiz-Santaliestra, M.E., Fernández-Benéitez, M.J., Marco, A., Lizana, M., 2010b. Influence of ammonium nitrate on larval anti-predator responses of two amphibian species. Aquat. Toxicol.99, 198-204.

Perrone, S.J., Meade, T.L., 1977. Protective effect of chloride on nitrite toxicity to coho salmon (Oncorhynchus kisutch) J. Fish. Res. Board Can. 34, 486-492.

Randall, D.J., Tsui, T.K., 2002. Ammonia toxicity in fish. Mar. Pollut. Bull. 45, 17-23.

Sampaio, L., Wasielesky, W., Campos Miranda-Filho, K., 2002. Effect of salinity on acute toxicity of ammonia and nitrite to juvenile Mugil platanus. Bull. Environ. Contam. Toxicol. 68, 668-674.

Serrano, L., Reina, M., Martín, G., Reyes, I., Arechederra, A., León, D., Toja, J., 2006. The aquatic systems of Doñana (SW Spain): watersheds and frontiers. Limnetica 25, 11-32.

Shinn, M.B., 1941. Colorimetric method for determination of nitrite. Ind. Eng. Chem. Anal. Ed. 13, 33-35

Shinn, C., Marco, A., Serrano, L., 2008. Inter- and intra-specific variation on sensitivity of larval amphibians to nitrite. Chemosphere $71,507-514$.

Smith, V., Tilman, G.D., Nekola, J.C., 1999. Eutrophication: impacts of excess nutrient inputs on freshwater, marine, and terrestrial ecosystems. Environ. Pollut. 10, 179-196.

European Union, 1986. Directive 86/609/EEC of 24 November 1986 on the approximation of laws, regulations and administrative provisions of the member states regarding the protection of animals used for experimental and other scientific purposes. Official J. Eur. Commun.

US EPA, 1986. Quality Criteria for Water. EPA 440/5-86-001. United States Environmental Protection Agency (US EPA). Washington, DC.

Vitousek, P.M., Aber, J., Howarth, R.W., Likens, G.E., Matson, P.A., Schindler, D.W., Schlesinger, W.H., Tilman, G.D., 1997. Human alteration of the global nitrogen cycle: causes and consequences. Ecol. Appl. 7, 737-750.

Wetzel, R.G., 2001. Limnology - Lake and River Ecosystems. Academic Press.

Williams, E.M., Eddy, F.B., 1986. Chloride uptake in freshwater teleosts and its relationship to nitrite uptake and toxicity. J. Comp. Physiol. 156, 867-872. 